\title{
Teachers' Problems and Solutions in Implementing Curriculum 2013
}

\author{
Yanuarti Apsari \\ yanuar.apsari1@gmail.com \\ STKIP Siliwangi Bandung
}

\begin{abstract}
Curriculum 2013 as an effort to reform educational system. However, the Curriculum demands teacher and school to be skilled and trained and because of this, in implementing School Based Curriculum teachers deal with some problems. Thus, this study aims to find out the problems faced by the English teacher in implementing Curriculum 2013 and their solution to overcome those problems. With regard to the purpose of the research, a qualitative approach was employed. The data were obtained through observation, questionnaires and documents. The data were transcribed, categorized, and interpreted to answer the research questions. The respondents of this study were three English teachers of three high school in Batujajar. The result of the study showed that dealing with the the implementation of Curriculum 2013 the teachers had the problem related to three aspects namely: problems related to teaching and learning process, problems related to creating lesson plan, and problems related with teaching material. It was also revealed that the respondents do some efforts to overcome those problems such as maximizing the provided facilities, cooperating with others teachers, getting involved in workshop or MGMP,searching the example of lesson plan from internet, reading the various sources, copying and using lesson plan from the other schools, download E book, asking for friend to send E book through email and using the previous book.
\end{abstract}

\section{Key Words: Curriculum 2013, Problem and Solution}

\section{Introduction}

Professional competency has been a major demand in the world of education. One of the important factors to increase the education quality is curriculum as argued by Sukmadinata (2000, see Susilo, 2008: 9) that curriculum is the core of the whole educational process since it becomes a guidance for achieving the educational goal. Accordingly, curriculum is defined as a set of plans and rules about goals, contents, and learning materials as well as the way of using it as guidance for implementation of learning activities that is aimed at a specific goal National Education Standardized Institution (BSNP, 2006). It indicates that curriculum contains a set of explicit and implicit intents that is concerned with facilitating teaching and learning activities and its development (Miller and Seller, 1985). Thus, it can be argued that that curriculum determine the success of the education system.

In the attempt to improve the quality of national education output, since 2013, when PP 322003 on the Standard National Education was implemented, School Based Curriculum which is well-known as Kurikulum Tingkat Satuan Pendidikan (KTSP) was gradually developed by Curriculum 2013. In this case, Curriculum 2013 is expected to enhance the quality of education by developing the structure of 
curriculum in national level and developing local content in local level. However, the change of curriculum has leaded to confusion faced by teachers.

As a guide in developing School Level based Curriculum, Curriculum 2013 demands teacher and school to be skilled and trained. In addition, the curriculum should be prepared and adapted based on the learning situation and future demand and because of this, in implementing Curriculum 2013 teachers deal with some problems. Thus, this research aims to find out the problems faced by the English teacher in implementing Curriculum 2013 and their solution to overcome those problems.

\section{Curriculum}

Curriculum is a set of plans and rules about goals, contents, and learning materials as well as the way of using it as guidance for implementation of learning activities that is aimed at a specific goal National Education Standardized Institution (BSNP, 2006). It is in line with this, Saylor et al (1981: 3, cited in Suprijadi, 2008) points that curriculum refers to a plan for providing sets of learning opportunities for person to be educated. It indicates that curriculum is obviously crucial in the teaching and learning process since it can guide the teachers to be able to achieve the educational objectives.

With this regard, it is undeniable that teachers' role is essential since they play as curriculum implementer. In this case, teachers are expected to be able to bring about intended learning outcomes as suggested by Cooper (1990: 3). In short, teacher plays an important role in the classroom especially in the instructional context of language learning such as the Indonesian EFL classroom (Macaro, 1997, quoted by Liando, 2010).

Regarding the importance of curriculum, thus, it can be argued that a sound curriculum is required to be implemented in order to achieve certain educational objective.

\section{Components in Curriculum}

According to Susilo (2008: 88), there are some components in new Curriculum. They are the objectives, teaching materials, teaching learning process, and assessment and evaluation.

\section{a. The Objective}

The simple definition given from Matheson (2011), the term "objectives" refers to what the teacher want the students able to do as the result of learning outcomes.In addition, according to the Permendiknas No.23, 2006 on the Graduate Competence standard for primary and secondary schools (Depdiknas, 2006), the teaching of English includes the four language skills: listening, speaking, reading and writing. 


\section{b. Teaching Material}

One measure which is used to make the process of teaching and learning effective is related to selecting and adapting materials. As stated by Silver (1997) that there is a high correlation between those who read a lot and those who improve in their comprehension and vocabulary acquisition when they read. Thus, the teacher should provide the students' preferable text in order to encourage them to keep reading.

\section{c. Teaching and Learning Process}

It is undeniable that teachers are often seen as the agent largely responsible for students' success in teaching and learning process as what argued by Cooper (1990: 3) that effective teacher is one who is able to bring about intended learning outcomes. In short, that teacher plays an important role in the classroom especially in the instructional context of language learning such as the Indonesian EFL classroom (Macaro, 1997, quoted by Liando, 2010).

Schulman (1992, cited in Maisa, 2009: 8) defines that professional English teacher is a teacher who can maintain a high level of students' involvement and whose students can reach the goal of teaching learning process. Thus, it is reasonably to say that professional teacher is someone who can cope with teaching tasks competently.

Furthermore, Richards (2001: 211) adds that teaching skill can be developed by the following ways: observation of experienced teachers, observation of training videos, short theory courses, practice teaching under the supervision of experienced teachers, and working with a mentor teacher. In short, it can be inferred that exploration of teaching is crucial to enhance the quality of teaching. The exploration of teaching can be done by applying some steps, namely collecting samples of teaching, analyzing the samples of teaching, appraising teaching based on the analysis, and deciding on changes in teaching behavior (Gebhard, 2000:21-26)

Referring to the arguments above, it can be inferred that in teaching of EFL, the value of the teachers depend not just on their ability to use language but also on their knowledge about language and their understanding on how to implement the knowledge to facilitate their students' learning (Harmer, 2003: 19).

\section{d. Assessment and Evaluation}

The last component of curriculum is assessment and evaluation. The importance of evaluation is supported by Nunan (1992:116) states that no curriculum model would be complete without an evaluation component. It means that the teachers and learners need to be involved in the evaluation process.

\section{Curriculum 2013}

The establishment of Curriculum 2013 was based on law No.20, 2003 about National Education System and Government Regulation no. 32, 2013 about national Education Standard. It is arranged by the units of education based on the Content Standard (Standar Isi) and Graduate Competence Standard (Standar Kompetensi 
Lulusan). In other words, Content Standard and Graduate Competence Standard is a basis framework and curriculum structure in developing the curriculum.

Content Standard covers Core Competence and Basic Competence including learning content, learning experience, subject and learning load. The Core Competence and Basic Competence are developed based on Graduate Competence Standard. Core Competence refers to a competence in a particular lesson that students must achieve. While, Basic competence is a minimum competency that students must acquire and Graduate Competence Standard refers to a qualification of graduate's capacity including

In developing curriculum and instructional planning, the school should be based on Core Competence which covers spiritual attitude (K1-1), social attitude (K12), knowledge (K1-3), and skill (K1-4). Basic Competence is arranged to achieve Core Competence. It is developed by considering learners'characteristics, prior knowledge and the characteristics of particular lesson. It is divided into four division including basic competence of spiritual attitude, basic competence of social attitude, basic competence of knowledge, and basic competence of skill.

\section{a. Lesson Plan}

Basically, lesson plan is a plan describing what will be done in the teaching and learning process in order to achieve the competences stated in the syllabus. Thus, lesson plan is crucial since it contains guidance for the teachers in carrying out their teaching. According to Brown (2001), the formats of lesson plans are vary, but there are some crucial elements that need to be existed in a lesson plan. They are: Goal, objectives, materials and equipment, and procedures, evaluation and extra-class work

\section{b. Teaching Material}

Teaching material in Curriculum 2013 is determined by the government. It is different from teaching material in KTSP which gives teachers a chance to develop teaching materials based on the school potentials, students' needs and ability and the need of the society around the school.

\section{c. Teaching and Learning Process}

Based on Curriculum 2013, teaching and learning activity should be characterized by learner-centered activity, joyful and challenging condition, and contextual learning. Accordingly, Contextual Teaching and Learning (CTL) is regarded as the appropriate approach to fulfill such requirement since it is an approach that involves the students in meaningful activities that can help them relate their knowledge in the classroom with the context (Suyatno, 2002 cited in Cahyono, 2008: 2).

In using CTL approach, the teacher can apply certain principle such as modeling, inquiry and learning community. In learning community, students can enhances broader skills of cooperation (Harmer, 2001) and work together and share ideas in completing academic task (Jacob, 1999: 13). In addition, Scientific Approach is also used in Curriculum 2013. In developing instructional activities is based on several steps includes observing, questioning, exploring, associating and communicating. 


\section{Research Methodology}

\section{Research Design}

This study employed qualitative research design. It is considered as the suitable research method since this study is aimed to describe the problems faced by English teachers in implementing Curriculum 2013 and their solution to overcome those problems. This study can also be regarded as a case study since it was conducted in a small scale, a single case, focus on one particular instance of educational practice (Nunan, 1992).

\section{Research Site}

This study was carried out in three high schools in Batujajar in which the researcher also works in one of those schools. There ara three English teachers who were selected as the respondents of this study.

\section{Data Collection}

The data were obtained through observation and questionnaires. Observation was conducted to gain the data on the implementation of curriculum 2013 in the classroom. In this study, the researcher acted as non participant observer. The researcher sat at back of the classroom, took notes on, and videotaped "what was said and done" (Van Lier, 1988). The observation was carried out twice due to the lack of times.

In addition, this study used open-ended questionnaires which were written in Bahasa Indonesia to ensure complete understanding of the items of by the participants. Open-ended questionnaire was adopted to allow the respondents to answer in their own words (Brown, 2009: 202). They were used to investigate the problems faced by the respondents in implementing Curriculum 2013 and their solutions to overcome those problems.

The last, in this study, the teachers' lesson plans and the teaching materials used by the teachers were regarded as documents.

\section{Data Analysis}

Data analysis is an important step in every research since it is the process of organizing and storing data in light of your increasingly sophisticated judgments (Alwasilah, 2000). The data of this study were analyzed through qualitative data analysis on the basis of the reseach questions. In analyzing the data, the researcher integrated and related the findings to the background of the study, mainly to the research questions, theories, and the methodology for classifying the data into manageable units as suggested by Emilia (2008: 201). In this case, data analysis in this study was conducted as simultaneously action during and after data collection. By doing this the researcher was able to consistently sharpen the focus of the study.

\section{Finding and Discussion}

Relating to the objective of this study, the data is presented under several themes: the problems faced by English teachers in implementing Curriculum 2013 and their solutions to overcome the problems. 


\section{The Problems Faced By English Teachers in Implementing Curriculum 2013}

\section{a. The Problems Related to Teaching and Learning Process}

Dealing with teaching and learning process, the respondents faced many difficulties in implementing School Based Curriculum as it is revealed from the questionnaires:

Teacher \#1 mentions that the obstacle in applying Curriculum 2013 is the limited facilities in the school. It is in line with teacher\#3 who states that the obstacle is dealing with school's facility. While, teacher \#2 says that the deciding the appropriate teaching method with the new curriculum. It is supported by teacher\#3 who mentions the lack of understanding in applying scientific approach and lack of school's facility as the problems.

Based on the statements above, there are some problems that are faced by the respondents such as limited school's facilities, teaching methods and lack of understanding in applying scientific approach as the characteristic of curriculum 2013.

From the finding above, it can be concluded that teaching facilities can affect the quality of teaching and learning process as explained by Richards (2001: 207) that the last set of factors that affect the quality of teaching in a program related to the institution context in which teachers work. Since the teachers are expected to teach well they need ongoing support from the others. Thus, in order to make teaching process successful, school need to provide adequate teaching facilities such as a multimedia lab or computer lab, language lab, self-access center, and students reading room.

Moreover, the data from observation revealed that the respondents faced different difficulty in developing English language teaching based on curriculum 2013.

Teacher\#1 had difficulties to manage the class. He divided the class into group discussion but it was not work well and the students were very noise. This indicates that he applied collaborative learning as recommended to use in curriculum 2013. While, teacher\#2 was seen to use different soources as teaching material. She not only used textbook as recommended by the government but also used the other sources to support her in teaching and learning process. This indicates that she got difficulty in using the Curriculum 2013 textbook.

Furthermore, it was found that teacher \#3 taught in the classroom without using scientific Approach as what she wrote in her lesson plan. It indicates that the teaching and learning process conducted in the classroom was not appropriate with the lesson plan.

In curriculum 2013, the teaching of English is developed with the framework of Scientific Approach and it seems to pose some challenges for the teachers. They should not only pay attention to linguistic aspects but also to strategic competence, socio cultural and discourse aspects. Given this challenge, the teachers who have been accustomed to conventional teaching which emphasizes on linguistics aspects need to switch to a new teaching paradigm. This finding showed that this new paradigm 
sometimes lead to the confusion and problems, for example: In Indonesia, there are 30-48 students in a classrooms. As a result the situation may not be effective.

From the result finding above, it can be concluded that the teachers are not ready to implement curriculum 2013. It is due to their lack of competences. It is irrelevant with the statement of (Sarimaya, 2008) that the teachers are demanded to have professional competence. The competence include knowledgeable in terms of subject matter, teaching and learning methodology and curriculum. This means that teachers are demanded to be professional teachers and have good teaching skills.

\section{b. The Problems Related with Creating the Lesson Plan}

It is revealed from the questionnaire that the teachers' problems dealing with creating lesson plan can be noticed below:

Q\#12 : what are your ptoblems in creating lesson plan? related with

Teacher\#1 : I have problem in creating the lesson plan. The obstacle is planning teaching procedures which is relevant to Basic Competence and Core Competence, especially in developing learning activities which give opportunity for students to use their English actively.

Teacher \#2 : I get confused to create the lesson plan, especially in developing indicator based on Basic Competence and Core Competence.

Teacher \#3 : The obstacle is that I actually do not know how to create the right lesson plan based on Curriculum 2013.

This findings above is supported from the document data. The lesson plan of teacher\#1 showed that in developing instructional activities are not based on several steps stated in Scientific Approach such as observing, questioning, exploring, associating and communicating. While, the lesson plan of teacher\#2 revealed that the respondent did not write the indicator for Basic competence and core competence 1 and 2. She only derived the indicator from Basic competence and core competence 3 and 4. In addition, the lesson plan of teacher\#3 showed that there is inconsistence between indicator, learning activities and assessments

From the data above, it can be concluded that there are several difficulties faced by the respondents in creating the lesson plan based on Curriculum 2013. The difficulties are difficulties are how to develop learning activities, indicator, and lesson plan. These imply that each respondent had different difficulties as they had different abilities and knowledge. It might due to lack of pedagogical competence as stated by (Sarimaya, 2008) that pedagogical competence covers the understanding of lesson planning. It might due to unsuccessful sozialization that conducted by the government. This means that Curriculum 2013 is still confusing especially for those who lack of understanding about curriculum 2013. Thus, a socialization of curriculum 2013 is crucial to conduct frequently. 


\section{c. The Problems Related with Teaching and Learning Material}

Relating with teaching material, it is revealed from the questionnaires that the respondents faced difficulty in obtaining the material. All respondents stated that until now curriculum 2013 books have not been distributed to the school yet.This means that the support is required to develop teachers' teaching skills and knowledge. The support can be provided in a form of adequate materials (Richards, 2001:213).

\section{Teachers' Solutions to Overcome their Problems}

The data from questionnaires revealed that respondents have several solutions to overcome their problems.

\section{a. Teachers' Solutions of the Problems in Teaching and Learning Process}

In relation to the problem emerge in the teaching and learning process, the three respondents describe the solution as the follow:

\footnotetext{
Q\#8 : How do you face the difficulty emerge in the classroom?

Teacher\#1 : my solution for my problem is that I tried to maximized the provided facilities.

Teacher\#2 : it is solved by cooperating with other teachers.

Teacher\#3 : I think the solution for the problem that I have stated is that we have to join workshop and MGMP in order to share ideas among the English teacher.
}

The data showed that in the attempt to solve the problems the respondents generally do cooperating with teachers and students, maximizing the provided facilities and finding out and enhancing the method which is suitable for learning material and joining workshop and MGMP.

This findings indicate that to improve teachers' knowledge, the school or the institutions should provide the opportunities for teachers to develop and update their professional knowledge and skills. It is also in line with the statement of Cahyono (2008) that getting involve in training and workshop session, real teaching, paper presentation and conference is one of teacher's effort in the attempt to develop English language teachers toward an understanding of the true sense of being professional.

Moreover, cooperating with other teacher can be often helpful in a school where there are teachers of different levels of experience and training. It is in line with the suggestion of Richards (2001: 211)that teaching skill can be developed by working with a mentor teacher. From the above finding it can be concluded that teachers need to realize the importance of their own professional growth. 


\section{b. Teachers' Solutions Related with Creating the Lesson Plan}

The following expressions are the respondents' solutions to overcome their problem in creating lesson plans.

Teacher\#1 : in solving the problem I try to search the example of lesson plan from

Q\#13 : What do you do in solving the problem in creating lesson internet and read the various sources.

can help

Teacher\#2 : sharing with other teachers in teacher association or MGMP solution.

teacher to improve thier knowledge about Curriculum 2013.

Teacher\#3 : copying and using the lesson plan of other school as the

Regarding the above statements, there are three solutions that respondents propose in the effort of solving the problems related to creating lesson plan including reading the various sources, sharing with other teacher in MGMP, copying and using the lesson plan of other school as the solution.

Reading various sources is in line with suggestion of Richards (2001: 212) that teachers need to develop curiosity and interest in many different aspects of teaching and expand their knowledge base about research, theory and issues in teaching.

Furthermore, sharing with other teacher in MGMP is supported by Mangkoesaputra (2004) that the program is intended to discuss teachers' problem regarding teaching and learning process. In short, the existence of MGMP can help teacher to design lesson plan and sole teachers' problem.

However, copying and using the lesson plan of other school is not suitable solution because each school may have different needs. If this condition still hapends it is assumed that the success of curriculum 2013 cannot be achieved. It implies that although the respondents had applied curriculum 2013 in their school, they realies that they had many weaknesses to apply curriculum 2013. Thus, in this case the government should provide a training program that has a high quality program.

\section{c.Teachers' Solutions Related with Teaching Material}

The following expressions are the respondents' solutions to overcome their problem in obtaining teaching materials.

Q\#11 : What are the obstacles that you face relating to teaching material? How do you do in solving the problem? Please explain.

Teacher\#1 : in solving the problem I downloaded E book and then it was printed and I asked the students to copy it.

Teacher\#2 : I asked my friend to send the material through email.

Teacher\#3 : I used the previous books which had been used last years. 
The data shows that there are many solutions to solve the problem concerning teaching material such as download E book, ask friend to send the material and used the previous book.

\section{Conclusions and Recommendations}

\section{Conclusions}

Some conclusions can be drawn based on the data from the questionnaires which were delivered to three teachers. It was found that the teachers' deep understanding on the theory of Curriculum 2013 does not guarantee that they can easily implement the curriculum as it is revealed from the findings. The data shows that dealing with the implementation of Curriculum 2013 the teachers had the problem related to three aspects namely: problems related to teaching and learning process, problems related to creating lesson plan, problems related to teaching and learning material.

Related to teaching and learning process, the respondents' problems are generally related to limited school's facilities, material especially for listening and teaching method. It indicates that teaching facilities can affect the quality of teaching and learning process. This is relevant with the statement of Richards (2001:207) that the last set of factors that affect the quality of teaching in a program related to the institution context in which teachers work. Since the teachers are expected to teach well they need ongoing support from the others. Thus, in order to make teaching process successful, school need to provide adequate teaching facilities such as a multimedia lab or computer lab, language lab, self-access center, and students reading room.

From the result finding above, it can be concluded that the teachers are not ready to implement curriculum 2013. It is due to their lack of competences. It is irrelevant with the statement of (Sarimaya, 2008) that the teachers are demanded to have professional competence. .

Concerning creating lesson plan, it was revealed that there are several difficulties faced by the respondents in creating the lesson plan based on Curriculum 2013. The difficulties are difficulties are how to develop learning activities, indicator, and lesson plan. These imply that each respondent had different difficulties as they had different abilities and knowledge. It might due to lack of pedagogical competence as stated by (Sarimaya, 2008) that pedagogical competence covers the understanding of lesson planning. It might due to unsuccessful sozialization that conducted by the government. This means that Curriculum 2013 is still confusing especially for those who lack of understanding about curriculum 2013. Thus, a socialization of curriculum 2013 is crucial to conduct frequently.

Relating to teaching and learning material, it is revealed from the questionnaires that the respondents faced difficulty in obtaining the material. All respondents stated that until now curriculum 2013 books have not been distributed to the school yet.This means that the support is required to develop teachers' teaching skills and knowledge. The support can be provided in a form of adequate materials (Richards, 2001:213). 
Regarding the problem related to teaching and learning process, respondents described their solution to those problems as revealed from the questionnaires. It was found that the respondents had different solutions in overcoming their problems during teaching and learning process. The solutions cover cooperating with others teachers, maximizing the provided facilities and joining workshop and teacher's association or MGMP in order to share the ideas among the English teachers.

It is also revealed that there are three solutions that respondents propose in the effort of solving the problems related to creating lesson plan including reading the various sources, sharing with other teacher in MGMP, copying and using the lesson plan of other school as the solution.

Moreover, the data shows that the respondents do some efforts to solve their problems related to teaching material, such as download E book, ask friend to send the material and used the previous book.

\section{Recommendations}

Based on the findings of the research, it is recommended for English teacher to improve their understanding about Curriculum 2013. It can be done through joining some trainings and workshops about curriculum 2013, reading a lot of sources, and sharing information with others teachers. In addition, the teachers also are expected to join some trainings and workshops about teaching of English covering methods, material, and media in order to improve their teaching.

The next recommendation is addressed for the institution. Dealing with the implementation of Curriculum 2013, the teachers are demanded to be skilled and trained. Therefore, the institution should provide opportunities for teachers to develop their professional knowledge and skills. Such opportunities can be provided through conference participation, workshops and in-service seminars, reading groups, peer observation, writing about teaching, project work and action research as suggested by Richards (2001). It is supported by Harmer (2001) who suggests that training is considered as one way to increase teachers' knowledge. In addition, the institutions are expected to facilitate the teachers to conduct MGMP.

Government needs to provide training and clear socialization about the implementation of Curriculum 2013 since most teachers seem confused in implementing Curriculum 2013. It can be seen from the inability of teachers to create lesson plan.

At last, due to this study conducted in a short period, it is recommended for the future researchers to investigate other aspects of the implementation of Curriculum 2013, such as about the assessment, the facilities, etc. 


\section{References}

Alwasilah, A. Chaedar. (2000). Pokoknya Kualitatif. PT. Dunia Pustaka Jaya \& Pusat Studi Sunda, Jakarta.

Brown, H.D. (2001). Teaching by Principles: An Interactive Approach to Language Teaching. White Plains, NY: Addison Wesley Longman.

Brown, J. D. (2009). “Open-Response Items in Questionnaires”. In Heigham, J. \& Crocker, R. A. (Eds.). Qualitative Research in Applied Linguistics. New York: Palgrave Macmillan.

Cahyono, B.Y. (2008). The Continous Improvement Learning Programmevvfor English Language Teachers: An Indonesian Experience. In M.E. Vethamani \& M.K. Kabilan (Eds) Practices and Issues in English Language Teacher Development. Petaling Jaya, . Malaysia: Sasbadi SDN. BHD.

Cooper, James. R. (1990). Classroom Teaching Skills. Toronto: D.C. Heath and Company.

Depdiknas. (2006). Peraturan Mendiknas Nomor 23/ 2006 Tentang SKL untuk Satuan Pendidikan Dasar dan Menengah. Jakarta: Departemen Pendidikan Nasional

Emilia, E. (2008). Menulis Tesis dan Disertasi. Bandung, Indonesia: Alfabeta.

Gebhard, J.G. (2000). Teaching English as a Foreign or Second Language. Ann Arbor: The University of Michigan Press

Harmer, J. (2001). The Practice of English Language Teaching. Edinburgh. UK: Longman

Harmer, J. (2003). How to Teach Writing. England: Longman.

Jacob, E. (1999). Cooperative Learning in Context: An Educational Innovation in Everyday

Classroom. Albany, NY: State University of New York.

Liando, Nihta.V.P. (2010). Students' VS Teachers' Persfectives on Best Teacher Characteristics in EFL Classrooms. TEFLIN Journal: Volume 21, Number 2, August . 2010.

Maisa. (2009). Teachers' Understanding of Characteristics of Professional English English for Young learners. Unpublished Undergraduate Thesis, Department of English Education: Indonesia University of Education.

Miller \& Seller. (1985). Curriculum Perspectives and Practices. Longman: New York

Nunan, D. (1992). The Learner-Centered Curriculum. New York: Cambridge University Press. 
Nunan, D. (2003). Practical English Language Teaching. New York: McGraw-Hill

Richards, J.C. (2001). Curriculum Development in Language Teaching. New York: Cambridge University Press.

Sarimaya, F. (2008). Sertifikasi Guru: Apa, Kenapa, dan Bagaimana (Teacher's Sertification: . What, Why, and How?). Bandung: Yrama Widya

Silverman, D. (2005). Doing Qualitative Research. London: SAGE Publication Ltd.

Susilo,M. Joko. (2008). Kurikulum Tingkat Satuan Pendidikan Manajemen Pelaksanaan dan Kesiapan Sekolah Menyongsongnya. Yogyakarta: Pustaka Pelajar

Suprijadi, D. (2008). The Implementation of School-Based Curriculum. Unpublished . Undergraduate Thesis, Department of English Education: Indonesia . University of Education.

Van Lier, Leo. 1988. The Classroom and the Language Learner. London: Longman 